\title{
Purification and Components Identification on Spinach (Amaranthus sp. L.) and Broccoli (Brassica oleracea L.) Fermented by Kombucha Culture as Source of Folic Acid Through Stirred Microfiltration Cell (SMFC)
}

\author{
Agustine Susilowati ${ }^{*}$, Aspiyanto, Puspa D. L., Hakiki M. and Yati M. \\ Research Centre for Chemistry, Indonesian Institute of Sciences, Kawasan PUSPIPTEK, Serpong, South Tangerang - \\ 15314, BANTEN, INDONESIA, \\ *Corresponding author, tel./fax.: (012) 7560929, e-mail: agustine_1408@yahoo.co.id
}

\begin{abstract}
Purifying spinach (Amaranthus sp.) and broccoli (Brassica oleracea L.) fermented by Kombucha culture through microfiltration (MF) membrane of $0.15 \mu \mathrm{m}$ fitted in Stirred Microfiltration Cell (SMFC) produced subsequently both fermented spinach and broccoli concentrates with compositions of folic acid of $58.9 \mu \mathrm{g} / \mathrm{mL}$ and $28.1 \mu \mathrm{g} / \mathrm{mL}$, total solids of $6.29 \%$ and $5.76 \%$, total acids of $0.57 \%$ and $0.93 \%$, polyphenol of $0.25 \%$ and $0.06 \%$, and reducing sugars of 105.34 $\mathrm{mg} / \mathrm{mL}$ and $66.09 \mathrm{mg} / \mathrm{mL}$. In these conditions, recovery of both fermented spinach and broccoli concentrates mentioned above were 1.07 times and 0.64 times, 0.95 times and 0.97 times, 1 times and 1 times, 3.57 times and 0.85 times, 1.22 times and 0.68 times compared to feed, Based on both the best molecular weight (MW) and relative intensity, dominant monomer was reached for fermented spinach extract and gave folic acid fractionation, folic acid and polyphenol with MW of 219.57 Dalton (Da.), 442.99 Da. and 192.11 Da., and relative intensities of $19.78 \%, 0.81 \%$ and $1.65 \%$, respectively.
\end{abstract}

Keywords: spinach (Amaranthus sp.), broccoli (Brassica oleracea L.), folic acid, SMFC, LC-MS.

\section{ABSTRAK}

Proses pemurnian melalui Sel Mikrofiltrasi Berpengaduk (SMFB) pada bayam dan brokoli terfermentasi oleh kultur Kombucha menggunakan membran mikrofiltrasi $0.15 \mu \mathrm{m}$ menghasilkan konsentrat bayam dan brokoli terfermentasi dengan komposisi asam folat $58.9 \mu \mathrm{g} / \mathrm{mL}$ dan 28.1 $\mu \mathrm{g} / \mathrm{mL}$, total padatan $6.29 \%$ dan $5.76 \%$, total asam $0.57 \%$ dan $0.93 \%$, polyfenol $0.25 \%$ dan $0.06 \%$, dan gula pereduksi $105.34 \mathrm{mg} / \mathrm{mL}$ dan $66.09 \mathrm{mg} / \mathrm{mL}$. Pada keadaan ini, perolehan kembali (recovery) konsentrat bayam dan brokoli terfermentasi pada masing-masing komponen tersebut diatas adalah 1.07 kali dan 0.64 kali, 0.95 kali dan 0.97 kali, 1 kali dan 1 kali, 3.57 kali dan 0.85 kali, dan 1.22 kali dan 0.68 kali dibandingkan dengan umpan, Berdasarkan pada berat molekul (BM) dan intensitas relatif terbaik, monomer dominan dicapai pada esktrak bayam terfermentasi dan memberikan pecahan asam folat, asam folat dan polyfenol ber BM 219.57 Dalton (Da.), 442.99 Da. dan 192.11 Da. dengan intensitas relatif 19.78 \%, $0.81 \%$ dan $1.65 \%$.

Kata-kata kunci: bayam (Amaranthus sp.), brokoli (Brassica oleracea L.), asam folat, SMFC, LC-MS

\section{INTRODUCTION}

Both spinach (Amaranthus sp.) and broccoli (Brassica oleracea L.) fermented by Kombucha culture are a novelty of fermentation process as an effort to produce naturally folic acid. Folic acid is recognized as very important intake to reduce all prenancies woman's risk from its emergence of neural tube birth defects 
(NTD) on infant [1]. There are a close relationship between supplementation of folic acid and prevention of its occurrence of foetal abnormalities condition [2], therefore all prenancies women and teen girls who could become pregnant should start folic acid consumption ideally at least four months before pregnant. Using Kombucha culture containing acetic acid bacteria (such as Acetobacter xylinum), yeast (Saccharomyces cereviseae, Saccharomyces ludwigii, Saccharomyces bisporus, Zygosaccharomyces sp.) and several fungi type (Torolupsis sp.) [3] are possibility able to degrade polyphenol and amino acids to folic acid through invertase enzyme. Similar process is occurred at Kombucha tea in order to increase total polyphenol and Ltheanine (glutamic acid) during fermentation process [4]. There are possibility a relationship between polyphenol and glutamic acids as a part of folic acid by activity of Kombucha culture invertase. Invertase enzyme will degrade and convert sucrose to organic acids (acetic acid, lactic acid, etc.) and decrease acidity level. In same time, protease enzyme from culture will degrade and convert vegetable protein to soluble amino acids, particularly glutamic acid linked by structure of folic acid. It had been known that folic acid is structured on glutamic acid, para amino benzoat (PABA) and ptreidin so that it increase of polyphenol will possibility raise glutamic acid, as well. Folic acid (folate, folacin, vitamin $\mathrm{B}_{9}$, pteroyl-L-glutamic acid, pteroyl-L-glutamate, pteroyl monoglutamic acid) [5] is kinds of component, which affect on the growth of brain, production of erythrosite and prevent of aneamia [6]. Activities on fermentation of bacteria and yeast does not only symbiosis to produce natural antibiotic materials, but also it produces vitamins of B1, B2, B3, B6, B12, B15 and E, mineral, folic acid and enzyme [7]. Besides, Kombucha culture may functionate as anti microbial agent [8] and hepatoprotective [9]. Lactic Acid Bacteria (LAB) at kombucha cultures have also potential use on gut environmental and the host health, acting as energy sources, regulators of gene expression and cell differentiation, and antiinflammatory agents. In fact, host-microbe interactions are essential for the resistance to pathogenic infections, gut development and epithelial homeostasis [10], [11].

Folic acid is a water-soluble B vitamin, not stable on light, oxygen, mechanic treatment, and high temperature so that process method selection, which is suitable and convenient will keep its presence of that activated compound. Stirred microfiltration cell (SMFC) used in purifying both fermented spinach and broccoli is selected because operation based difference in molecular weight (MW) and particles size, operate at room temperature, no change of state (liquid to gas), no need and no add other chemical substances, convenient operation and maintenance, and lower energy consumption, operates continuous, and low floor space requirements [12], therefore it will be suitable for separating and purifying compounds involving heat sensitivity and folic acid keeping. Use of $0,15 \mu \mathrm{m}$ microfiltration (MF) membrane will separate folic acid based on particles size, in which MF membrane is able to separate macromolecular larger than 500.000 $\mathrm{g} / \mathrm{mol}$ (particle size $0.1-10 \mu \mathrm{m}$ ) [13]. Folic acid is predicted to pass freely in permeate, except its presence of 'fouling' so that it is trapped on 'cake' in retentate [14]. Applying SMFC in separating biomass of both fermented spinach and broccolo were conducted to find out characteristic of SMFC toward larger process (module). Although, it had been known that SMFC has different specification with cross-flow microfiltration (CFMF) module. In SMFC, MF membrane retains particles on the top membrane surface and consequently yield in the build-up of a filter cake. This reduces flow and must be replaced, removed and regenerated [15]. In addition, the presence of the build-up of a filter cake radically alters filtering characteristics and membrane performance (flux, rejection of solutes). While, cross-flow circulation in MF membrane operation creates turbulence and sweep away solutes at the membrane surface, that prevents solutes settling.

The purpose of this experimental activity was to find out component compositions, particularly folic acid and monomer characteristic from retentates (concentrates) and permeates as a results of purification of both spinach and broccoli fermented by Kombucha culture as functional food for smart food through MF membrane $(0.15 \mu \mathrm{m})$ fitted in SMFC at fixed process condition (stirrer rotation speed $400 \mathrm{rpm}$, room temperature and pressure 40 psia for 30 minutes).

\section{EXPERIMENTAL SECTION}

\subsection{Materials}

Main materials used in this experimental activity were distilled water, blanched spinach (Amaranthus sp.), blanched broccoli (Brassica oleracea), sucrose purchased from local market, Kombucha culture (Research Centre for Chemistry - LIPI), $0.15 \mu \mathrm{m}$ microfiltration (MF) membrane (Fluoro polymer, FSM-0.15-PP, Alfa 
Laval, Denmark), chemical reagents for process and analyses. While, all chemical reagents used were of analytical grade or purer, and solutions were based on highly purified water (distilled water).

\subsection{Equipments and instrument analysis.}

Main important equipments utilized in this experimental activity were fermentation system, laminar flow system, water bath (Memmert, Germany), incubator, cylindrical tank for technical nitrogen (Local), pressure gauge of technical nitrogen (Fisher Scientific Company, England), Dead-End Stirred Ultrafiltration Cell (SUFC) (MILLIPORE, Model 8200, U. S. A.), UV-Vis Spectrophotometer (Model RF-550, Shimadzu, Japan) and LC-MS (Mariner Biospectrometry) with LC (Hitachi L 6200).

\subsection{Experimental Design and Analysis}

Experimental work was conducted by using biomass filtrates of fermented spinach and broccoli by Kombucha culture sieved via 100 mesh. was further purified by means of MF membrane $(0.15 \mu \mathrm{m})$ equipped in SMFC [16] to produce retentate (concentrate) and permeate. Analysis were performed on total solids (Gravimetric method), dissolved protein (Lowry method) [17], N-amino (Copper method) [18], total polyphenol (Folin-Denis Method) [19], folic acid (spectrophotometri UV-Vis) [20]. Identification on monomer biomass was conducted by LC-MS (Mariner Biospectrometry) with LC (Hitachi L 6200) [21]. Process and analysis were conducted in duplicate. Data were processed in this description based on result of average analysis.

\subsection{Process Steps}

Preparation of inoculum and fermentation process of spinach and broccoli.

A number of blanched spinach filtrate and blanched broccoli filtrate sieved via 100 mesh was added sucrose (10\%, w/v vegetable filtrate) and Kombucha culture (15\%, v/v), and fermented in closed container in dark room for 5 days. Product of fermentation process is fermented spinach inoculum and fermented broccoli inoculum. Respectively, a number of fresh and clean spinach and broccoli were blanced at $80{ }^{\circ} \mathrm{C}$ for 15 minutes and $80{ }^{\circ} \mathrm{C}$ for 5 minutes, pulverized at a $1: 4$ ratio of blanched broccoli and spinach to water (sterile) until vegetable suspension is reached, and filtered through 100 mesh sieve to produce broccoli filtrate and spinach filtrate, and residues. Broccoli filtrate was further added with broccoli inoculum $15 \%$ (v/v filtrate) and sucrose $10 \%$ (w/v filtrate), and stored in closed container using cassa cloth in dark room at room temperature for 5 days. Same method and process condition is done for spinach filtrate. All fermentation activities were aseptically. Recovery of each biomass is introduced as feed in purifying process folic acid through MF membrane $(0.15 \mu \mathrm{m})$.

\section{Separation of fermented spinach and broccoli by SMFC}

A number of biomass of fermented spinach suspension was filtered through 100 mesh sieve, and microfiltered via $0.15 \mu \mathrm{m}$ MF membrane equipped in SMFC at stirrer rotation speed $400 \mathrm{rpm}$, room temperature and pressure 40 psia for 30 minutes. Same method and process condition is done for fermented broccoli suspension. The commercial MF membrane disc having a pore size of $0.15 \mu \mathrm{m}$ with the glossy skin side toward solution was placed into the Stirred Microfiltration Cell (SMFC) and connected to a nitrogen gas cylinder. A SMFC of $180 \mathrm{~mL}$ capacity and a membrane area of $30.175 \mathrm{~cm}^{2}$ was operated in the filtration experiments [16]. Each MF membrane was first compacted at 40 psia for 5 minutes. After that, operation of SMFC was stopped and distilled water was drained. The suspension of fermented spinach filtrate was added to the SMFC. Operation conditions were stirrer rotation speed of $400 \mathrm{rpm}$ and trans-membrane pressure (TMP) of 40 psia for 30 minutes. All MF experiments were done at a room temperature. Volumetric permeate flow rate was measured after each $\mathrm{mL}$ of permeate collected. Samples of permeate were collected and recorded for 30 minutes. Permeate and retentate (concentrate) were regularly sampled for analysis of their folic acid, total solids, dissolved protein, N-Amino, reducing sugar and kind of monomer by LC-MS.

Identification of folic acid, glutamic acid and pholyfenol in both fermented spinach and broccoli via LC-MS

Sample of fermented spinach and fermented broccoli extract was microfiltered using $0.15 \mu \mathrm{m} \mathrm{MF}$ membrane equipped in SMFC at room temperature for 30 minutes until it yields permeate and retentate (concentrate) [16]. Permeate was collected and introduced as material sample for identification of protein isolate monomer through LC-MS using Mariner Biospectrometry. LC system was integrated with Q-tof mass spectrometer via Electro Spray Ionization (ESI) system, in which scan mode was done at range of 100 - 
$1200 \mathrm{mz}$ and $140{ }^{\circ} \mathrm{C}$. LC (Hitachi L 6200) using C18 (RP 18) Supelco column with long $250 \mathrm{x} 2 \mathrm{~mm}$ and particles size $5 \mu \mathrm{m}$. Kinds of solvent were water containing $0.3 \%$ Acetic Acid (A) and methanol containing $0.3 \%$ Acetic Acid (B) at a 90 parts of methanol : 10 parts of water ratio at flow rate $1 \mathrm{~mL} / \mathrm{minute}$ and injection volume of $20 \mu \mathrm{L}$ [21].

\section{RESULTS AND DISCUSSION}

\subsection{Characteristic of material}

Blanching process on spinach and broccoli aims to produce vegetables maturity, as shown in Figures 1. Blanching process is performed in order to inactivate enzyme (peroksidase and katalase), kill microbes, clean vegetables from dirty, and lose unsuitable flavour. This process affects on composition from the whole vegetables, particularly total solids [22]. Fermentation process causes a physical change, especially color in fermented spinach suspension from fresh green then pale green to brownish yellow (5 days of fermentation) followed by fresh aroma like vinegar, as shown in Figures 2. Fermentation process of spinach and broccoli for 5 days increase folic acid, reducing sugars, total acids and total polyphenol, and decrease total solids in biomass. Although, it is occurrence a dropping compositions after blanching process, and increase after fermentation, shown in Table 1. Increasing folic acid and total polyphenol was possibility caused by activities of microbe in Kombucha culture through biosynthesis (de novo biosynthesis) [23] of amino acids (adenine, histidine, methionine) both on Kombucha culture (fungi, bacteria, yeast) and on leaves. These biosynthesis covers enzyme activities of dihydrofolate synthase (DHFS) and folypolyglutamate synthase (FPGS) to form dihydrofolate It is a derivate of folic acid [23], in which this process is only take placed on plants and microbes [24]. Increase of total acids are possibility caused by enzyme activity of Kombucha culture invertase using sucrose for its metabolisme to form organic acids (lactic, malic, acetic, ethanol, acetaldehyde and other) with fresh aroma like alcohol [3] counted as total acids [17]. Fermented spinach is a suspension with more brown color and produces fresher aroma compared to fermented broccoli. By increasing total acids causes its occurrence of dropping total solids by fermentation process and dissolving a part of solids, as indicated in Figures 3. In this fermentation uses sucrose as carbon source. This matter seems in difference between reducing sugars concentration as fresh spinach/broccoli and after lower blanching, and increase after fermentation. Increase of reducing sugars is possibility caused by a part of sucrose consumed by microbes as a consequence of its occurrence of lysis by rising acids with long fermentation time. Reducing sugars of biomass is a remain of sucrose after fermentation operation, in which sucrose forms organic acids effected by an amount of starter, environmental condition and enzyme activities of invertase in forming the metabolite. Besides, sucrose is used by bacteria of $A$. xylinum in order to form cellulose as 'nata/pelikel' and buoyancy on medium surface [7].
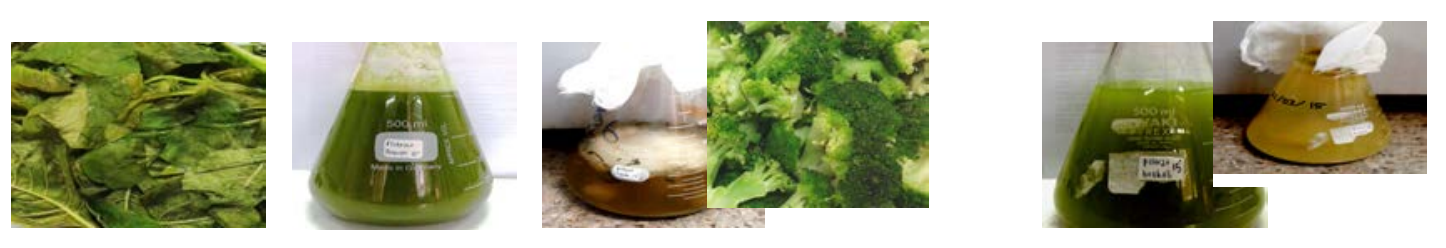

Figure 1. (a) Blanched spinach, (b) suspension of blanched spinach, (c) fermented spinach at 5 days, (d) blanched broccoli , (e) suspension of blanched broccoli and (e) fermented broccoli at 5 days.
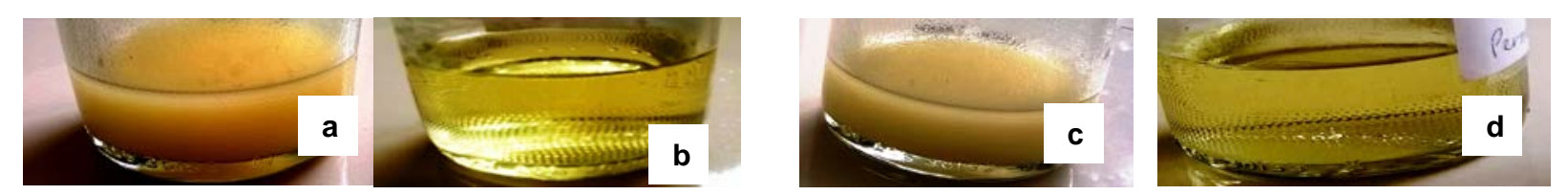

Figure 2. (a) fermented spinach concentrate, (b) fermented spinach permeate (extracts) (c) fermented broccoli concentrate and (d) fermented broccoli permeate (extracts) at optimum process condition through $0.15 \mu \mathrm{m}$ MF membrane. 

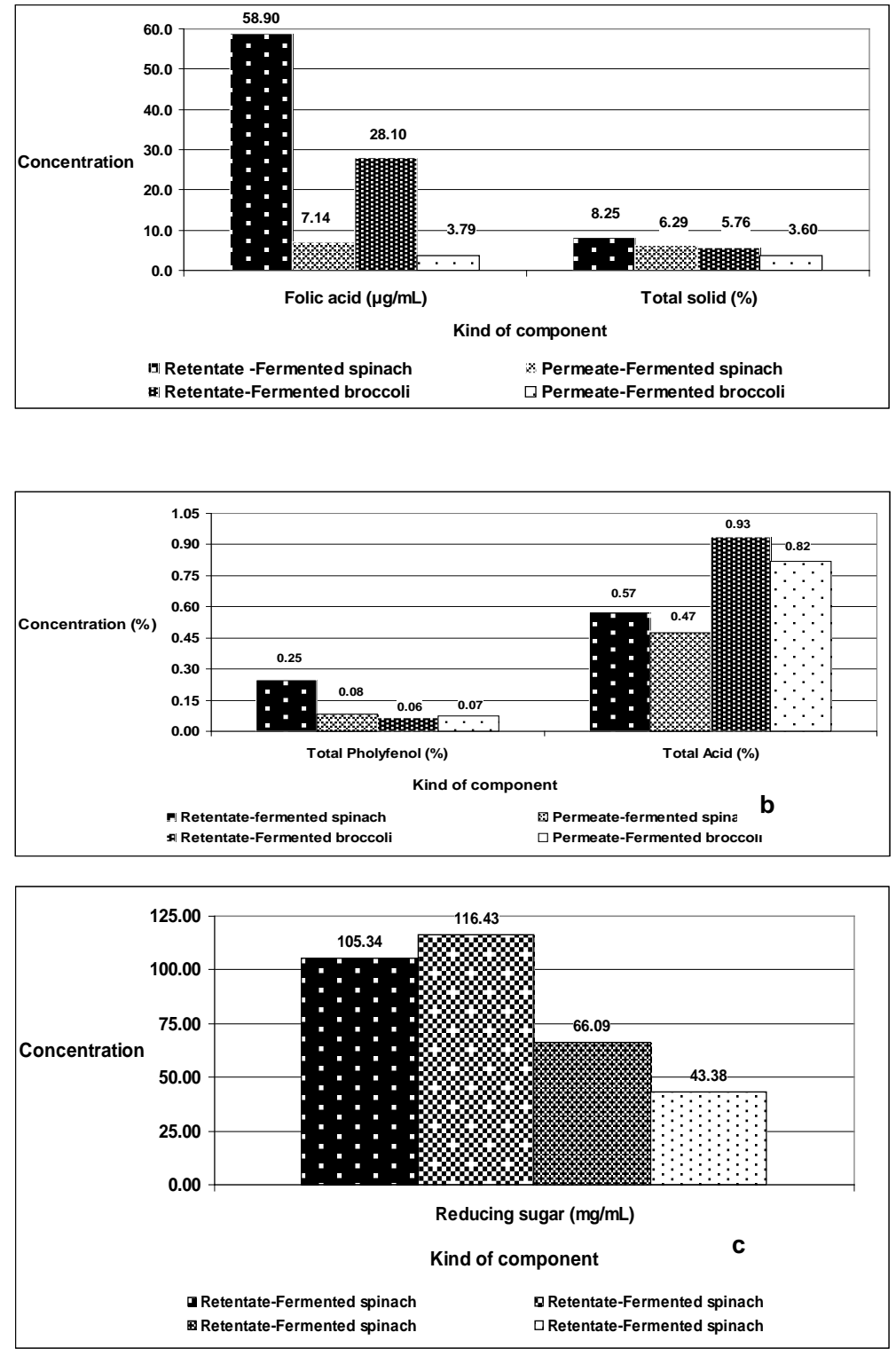

Figure 3. Recovery of (a) folic acid and total solids ; (b) total pholyfenol and total acid; (c) reducing sugar in retentate and permeate of fermented spinach and broccoli biomass through $0.15 \mu \mathrm{m}$ MF membrane.

\subsection{Effect of purification on both fermented spinach and broccoli by SMCF}

Folic acid $(\mu \mathrm{g} / \mathrm{mL})$ and total solid (\%)

Purification process on both fermented spinach and broccoli by means of $0.15 \mu \mathrm{m}$ MF membrane equipped in SMFC at stirrer rotation speed $400 \mathrm{rpm}$, room temperature and pressure 40 psia for 30 minutes gave a separation of folic acid and total solids successfully from each kind of biomassa, as displayed in Figure 2a. More folic acids were retained in retentate compared to pass it freely in permeate for both kind of biomass. This matter is possibility caused by the presence of fouling in order to form 'cake' layer on the top membrane surface as a consequence of high difference in folic acid concentration at both in retentate and permeate. Particles size of folic acid with ranging from 0.008 to $0.01 \mu \mathrm{m}$ [25] or $0.001-0.01 \mu \mathrm{m}$ [26] should more much passing in permeate compared to in retentate. Fouling is possibiliity caused by specific physical and chemical interactions between various soluble solids in membrane [13], [27]. In this matter, folic acid was trapped and linked in other components so that it pass only a part of folic acid in permeate. It is showed at recovery of total solids with similar profile. Total solids are accumulation of the whole components both 
soluble and insoluble. Retentate of fermented spinach retains more much folic acid and total acids and pass it more much in permeate compared to fermented broccoli.

Biomass of fermented spinach had possibility components with larger particles size than specific pore size of MF membrane $(0.15 \mu \mathrm{m})$ because biomass was predominated by Kombucha culture consist of yeast, fungi and bacteria $(1-2.5 \mu \mathrm{m})$ and organic acids $(0.001-0.01 \mu \mathrm{m})$ [26]. While, biomass of fermented broccoli has possiblity had components with smaller particles size compared to biomass of fermented spinach but the components had smaller particle size than that specified pores size of MF membrane $(0.15 \mu \mathrm{m})$. By rotation force in SMFC, particles will settle and was retained via gravitation force (pressure 0 psia), so that by enlarge of pressure (40 psia) will causes its occur of components settling on the top membrane surface. SMFC retains both more much folic acid in biomass of fermented spinach $(58.90 \mu \mathrm{g} / \mathrm{mL})$ and folic acid in biomass of fermented broccoli $(28.10 \mu \mathrm{g} / \mathrm{mL})$ compared to pass it as permeates, namely $7.15 \mu \mathrm{g} / \mathrm{mL}$ dan $3.78 \mu \mathrm{g} / \mathrm{mL}$. Based on membrane selectivity and process efficiency compared to folic acid in retentate and permeate, SMFC was able to separate both folic acid in biomass of fermented spinach retentate and folic acid in biomass of fermented broccoli retentate of $89.17 \%$ and $88.13 \%$. In other words, recovery of folic acid from both biomass of fermented spinach and broccoli in retentate and permeate, namely $66.05 \mu \mathrm{g} / \mathrm{mL}$ and $31.885 \mu \mathrm{g} / \mathrm{mL}$ to $58.9 \mu \mathrm{g} / \mathrm{mL}$ and $28.1 \mu \mathrm{g} / \mathrm{mL}$. When compared to initial material of both fermented spinach and broccoli, SMFC increases recovery of folic acid in consentrates, namely from $54.83 \mu \mathrm{g} / \mathrm{mL}$ to $58.9 \mu \mathrm{g} / \mathrm{mL}$ (1.07 times) and from $43.09 \mu \mathrm{g} / \mathrm{mL}$ to $28.1 \mu \mathrm{g} / \mathrm{mL}$ (0.64 time).

SMFC was able to separate total solids in both biomass of fermented spinach and fermented broccoli retentates from $14.54 \%$ to $8.25 \%$ (0.56 times) and from $9.36 \%$ to $5.76 \%$ (0.61 times), respectively. Compared to both initial materials of fermented spinach and fermented broccoli, SMFC increases total solids in concentrate from $8.25 \%$ to $7.90 \%$ (95.75 \% or 0.95 times) and $5.76 \%$ to $5.60 \%$ (97.22 \% or 0.97 times), respectively. At this interpretation, optimization of folic acid in retentate (concentrate) was reached by kind of fermented spinach.

Total polyphenol (\% w/w) and total acid (\%w/v)

The presence of total polyphenol in both biomass of fermented spinach and fermented broccoli are relating with the presence of initial material, whereas total acids are metabolite produced during fermentation process. SMFC was able to retain total polyphenol in biomass of fermented spinach in retentate $(0.25 \%$, w/w) and pass freely total polyphenol in biomass of fermented spinach in permeate $(0.08 \%$, w/w $)$. The formation of 'cake' layer on the top surface of membrane was possibility predicted by difference in sufficient high polyphenol concentrations in retentate and permeate. Different trend could be showed on biomass of fermented broccoli, in which fouling is not occurred because total polyphenol penetrates more much in permeate $(0.06 \%, \mathrm{w} / \mathrm{w})$ compared with retained on the top surface of membrane $(0.07 \% \mathrm{w} / \mathrm{w})$, as displayed in Figure 2b. It had been indicated that polyphenol in vegetables have various MW larger than $600 \mathrm{Da}$.) [19] or particles size ranging from 0.001 to $0.01 \mu \mathrm{m}$ [26].

The presence of fouling in these biomasses indicated that the components have both smaller particles size and MW so that operation condition supports to process separating and passes more much polyphenol in permeate. Enzymatic activity of katalase presented in fungi, especially Candida tropicalis as dominant factor in Kombucha culture [28] is predicted to degrade and convert polyphenol to polyphenol derivatives with lower MW during fermentation process so that fermented suspension has also antioxidant property, as shown in Kombucha tea [2]. Based on membrane selectivity and process efficiency compared to total polyphenol in retentate and permeate, SMFC was able to separate both total polyphenol in biomass of fermented spinach retentate from $0.33 \%$ to $0.25 \%$ (75.76 \%) and in biomass of fermented broccoli retentate from $0.13 \%$ to $0.06 \%$ (46.15\%). Compared with both initial material of fermented spinach and fermented broccoli, SMFC raises total polyphenol in retentate from $0.25 \%$ to $0.07 \%$ (357.14 \% or 3.57 times) and from $0.06 \%$ to $0.05 \%$ (85.71\% or 0.85 times).

SMFC retains also more much total acids in both biomass of fermented spinach retentate and biomass of fermented broccoli retentate of $0.57 \%$ and $0.93 \%(\mathrm{w} / \mathrm{v})$ than that passing in permeate of $0.47 \%$ and $0.82 \%$ (w/v). Total acids are accumulation process on the whole organic acids (acetic acid, lactic acid, malic acid, acetaldehyde) as metabolite result during fermentation. Sucrose $(10 \% \mathrm{w} / \mathrm{v})$ is carbon source used for microbes metabolites (yeast and acetic acid bacteria) during fermentation [7] producing glucose and fructose 
followed by converting to gluconic acid and to acetic acid. These organic acids have particles size ranging from $0.001-0.01 \mu \mathrm{m}$ [26]. This matter showed occurrence of 'intermediate pore blocking' in which smaller solute particles (organic acids) than membrane pores size are accumulated and trapped to cover the top surface of membrane indicated by difference in insufficient high concentration of total acids in retentate and permeate. Based on membrane selectivity and process efficiency compared to total acids in retentate and permeate, SMFC was able to separate total acids in both biomass of fermented spinach retentate from $1.04 \%$ to $0.57 \%$ (54.81\%) and biomass of fermented broccoli retentate from $1.75 \%$ to $0.47 \%$ (26.86 \%). At this interpretation, optimization of total acids in retentate (concentrate) was reached by kind of fermented spinach. Compared to initial materials of fermented spinach and broccoli, SMFC increase total acids in retentate (concentrate) from $0.58 \%$ to $0.57 \%$ (101.75 \% or 1.01 times) and $0.97 \%$ to $0.93 \%$ (104.3\% or 1.04 times).

\section{Reducing sugar $(\mathrm{mg} / \mathrm{mL})$}

Reducing sugar of biomass is sugar remains, that is not fermented by Kombucha culture caused by internal factors of fermentation. Adding sucrose (10\%) as carbon source for microbes produce ethanol, acetaldehyde, organic acids affected by starter, environmental condition and invertase enzyme activity of microbes. MF membrane passes freely more much reducing sugar in biomass of fermented spinach (116.43 $\mathrm{mg} / \mathrm{mL}$ ) compared to retains it in retentate $(105.34 \mathrm{mg} / \mathrm{mL})$. In other words, SMFC does not represent fouling radically, because difference in reducing sugar concentration in retentate and permeate is insufficient high. It had been takes place 'internal pore blocking', a form of fouling caused by occurrence of reducing membrane pores size by accumulating or depositing particles (reducing sugar) in membrane or within membrane pores. This conditiopn can increase membrane resistant. Different trend is showed on biomass of fermented broccoli, in which MF membrane fitted in SMFC was able to retain more much reducing sugar in retentate $(66.09 \mathrm{mg} / \mathrm{mL})$ than that passes in permeate $(43.38 \mathrm{mg} / \mathrm{mL})$. In other words, it takes place 'intermediate pore blocking' in which difference in reducing sugar concentration in retentate and permeate is insufficient discrimination, as demonstrated in Figure 2c. Based on membrane selectivity and process efficiency compared to reducing sugar in retentate and permeate, MF membrane equipped in SMFC was able to separate and recover reducing sugar in both biomass of fermented spinach retentate from $221.77 \mathrm{mg} / \mathrm{mL}$ to $105.34 \mathrm{mg} / \mathrm{mL}$ (47.5 \%) and biomass of fermented broccoli retentate from $109.47 \mathrm{mg} / \mathrm{mL}$ to $66.09 \mathrm{mg} / \mathrm{mL}$ (60.37\%). At this interpretation, optimization of reducing sugar in retentate (concentrate) was reached by kind of fermented broccoli. Compared to initial materials of fermented spinach and broccoli, MF membrane fitted in SMFC raise reducing sugar in retentate (concentrate) from $86.30 \mathrm{mg} / \mathrm{mL}$ to $105.34 \mathrm{mg} / \mathrm{mL}$ ( $122.06 \%$ or 1.22 folds) and from $96.51 \mathrm{mg} / \mathrm{mL}$ to $66.09 \mathrm{mg} / \mathrm{mL}$ ( $68.48 \%$ or 0.68 folds).

From result of study for all purification were technically able to separate and retain bioactive components in both fermented spinach with concentrations of folic acid $58.9 \mu \mathrm{g} / \mathrm{mL}$, total solids $8.25 \%$, total acids $0.57 \%$, reducing sugar $105.34 \mathrm{mg} / \mathrm{mL}$ and total polyphenol $0.25 \%$, and fermented broccoli with concentrations of folic acid $28.1 \mu \mathrm{g} / \mathrm{mL}$, total solids $5.76 \%$, total acids $0.93 \%$, reducing sugar $66.1 \mathrm{mg} / \mathrm{mL}$ and total polyphenol $0.06 \%$. Whereas, permeate contains bioactive components in both fermented spinach with concentrations of folic acid $7.14 \mu \mathrm{g} / \mathrm{mL}$, total solids $6.29 \%$, total acids $0.47 \%$, reducing sugar 116.43 $\mathrm{mg} / \mathrm{mL}$ and total polyphenol $0.08 \%$, and fermented broccoli with concentrations of folic acid $3.78 \mu \mathrm{g} / \mathrm{mL}$, total solids $3.6 \%$, total acids $0.82 \%$, reducing sugar $43.38 \mathrm{mg} / \mathrm{mL}$ and total polyphenol $0.074 \%$. Figures 3a and $3 \mathrm{~b}$ demonstrated fermented concentrate dan permeat fermented spinach, Figures $3 \mathrm{c}$ dan $3 \mathrm{~d}$ demonstrated fermented concentrate dan permeate fermented broccoli.

\subsection{Identification of folic acid component in both fermented spinach and broccoli} Standard folic acid, standard glutamic acid and standard galic acid as pholyfenol

Identification of standard folic acid was reached 1 peak (T3.1) with retention time $0-10$ minutes and relative intensity $100 \%$, as indicated in Figure 4a. Mass spectra $69-1200 \mathrm{mz}$ from peak T3.1 indicated dominant compound with MW 267.2922 Da. and relative intensity $100 \%$ and other monomer predicted as folic acid is degraded by using LC-MS, as indicated in Figure 4b and Table 2. Folic acid has MW 441 Da. [29]. and relative intensity $77 \%$, while folic acid derivates are glutamic acid, tetrahydroxy folic and other, which is possibility predominant compound with MW 148.1576 - 444.4982 Da. On standard glutamic acid is reached 1 peak (T3.0) with retention time $0-10$ minutes and relative intensity $100 \%$, in which mass spectra $111-784 \mathrm{mz}$ from peak T3.0 showed dominant compound with MW 148.1479 Da. (100\%), as indicated in 
Figures 4c and 4d and Table 3. Its presence of glutamic acid was shown by assumption that glutamic acid is part of folic acid. Through LC-MS had been known that one compound displays difference in MW, in which it is possibility as $\mathrm{M}^{+}, \mathrm{M}^{+} \mathrm{Na}^{+}, 2 \mathrm{M}^{++}$or $2 \mathrm{M}^{+}+\mathrm{Na}^{+}$. This matter is caused by its presence of ionization because sensitify of LC-MS instrument relating with eluent used. Operation condition of LC-MS instrument is injection volume of $2 \mu \mathrm{L}$ and flow rate $0.05 \mathrm{~mL} /$ minute with eluent mixtures of methanol and water (containing $0.3 \%$ acetic acid) at ratio $80: 20$ using column of C-18 $(15 \mathrm{~mm}$ x $1 \mathrm{~mm})$ [21]. Identification on standard polyphenol as galic acid indicated chromatogram recovery with one (1) peak (T2.8) and relative intensity $100 \%$ as displayed in Figure 4e, in which at mass spectra $111-784 \mathrm{mz}$ from peak T2.75 displayed dominant compound with MW 193.1289 Da. (100\%) followed by compound with MW 194.1131 Da. (6 \%), as displayed in Figure $4 \mathrm{f}$ and Table 4. It had been known that MW of galic acid as polyphenol is approximately $193 \mathrm{Da}$.

Table 1. Composition of vegetable materials as feed and as a result of purification of folic acid in fermented vegetables through $0.15 \mu \mathrm{m}$ MF membrane.

\begin{tabular}{|c|c|c|c|c|c|}
\hline \multirow{2}{*}{$\begin{array}{l}\text { Kind of } \\
\text { material }\end{array}$} & \multicolumn{5}{|c|}{ Compositions } \\
\hline & $\begin{array}{l}\text { Total solid } \\
\text { (\%) }\end{array}$ & $\begin{array}{c}\text { Total } \\
\text { polyphenol } \\
(\% \mathrm{w} / \mathrm{w})\end{array}$ & $\begin{array}{c}\text { Folic acid } \\
(\mu \mathrm{g} / \mathrm{mL})\end{array}$ & $\begin{array}{c}\text { Reducing } \\
\text { sugar } \\
(\mathrm{mg} / \mathrm{mL})\end{array}$ & $\begin{array}{c}\text { Total } \\
\text { acid }(\%)\end{array}$ \\
\hline Fresh Spinach & 12.35 & 0.19 & 18.16 & 48.31 & 0,73 \\
\hline $\begin{array}{l}\text { Blanched } \\
\text { spinach* }\end{array}$ & 5.04 & 0.69 & 14.90 & 17.04 & 0.10 \\
\hline $\begin{array}{l}\text { Suspension of } \\
\text { blanched spinach }\end{array}$ & 9.50 & 0.04 & 22.86 & 46.68 & 0.19 \\
\hline $\begin{array}{l}\text { Fermented } \\
\text { spinach (5 days)** }\end{array}$ & 7.90 & 0.07 & 54.83 & 86.30 & 0.58 \\
\hline Fresh Broccoli & 10.65 & 0.93 & 21.83 & 11.49 & 0.34 \\
\hline $\begin{array}{l}\text { Blanched } \\
\text { broccoli* }\end{array}$ & 5.13 & 0.27 & 26.85 & 15.13 & 0.10 \\
\hline $\begin{array}{l}\text { Suspension of } \\
\text { banched broccoli }\end{array}$ & 8.91 & 0.02 & 30.76 & 36.64 & 0.38 \\
\hline $\begin{array}{l}\text { Fermented } \\
\text { broccoli (5 } \\
\text { days)** }\end{array}$ & 5.60 & 0.05 & 43.09 & 96.51 & 0.97 \\
\hline
\end{tabular}

Legend : *at 15 minutes (spinach) and 5 minutes (broccoli) at $80^{\circ} \mathrm{C} \mathrm{f;} * *$ as feed.

Table 2. Mononer dominant on mass spectra of folic acid standar.

\begin{tabular}{|l|l|l|l|l|l|l|l|}
\hline Index & $\begin{array}{c}\text { Centroid } \\
\text { Mass }\end{array}$ & $\begin{array}{l}\text { Relative } \\
\text { Intensity }\end{array}$ & Area & Index & $\begin{array}{c}\text { Centroid } \\
\text { Mass }\end{array}$ & $\begin{array}{c}\text { Relative } \\
\text { Intensity }\end{array}$ & Area \\
\hline 1 & 148.157631 & 11.37 & 95.19 & 21 & 289.278878 & 13.14 & 104.16 \\
\hline 2 & 148.546075 & 1.34 & 15.39 & 24 & 337.355276 & 3.65 & 48.30 \\
\hline 13 & 221.734988 & 21.69 & 177.84 & 26 & 442.496215 & 50.55 & 631.03 \\
\hline 16 & 233.245128 & 2.27 & 13.33 & 27 & 443.166533 & 8.35 & 24.35 \\
\hline 18 & 267.292185 & 100.00 & 1025.63 & 28 & 443.509427 & 14.98 & 60.46 \\
\hline 19 & 268.291245 & 15.71 & 89.71 & 29 & 444.479853 & 2.44 & 78.59 \\
\hline
\end{tabular}

Table 3. Mononer dominant on mass spectra glutamic acid standar. 


\begin{tabular}{|l|l|l|l|l|l|l|l|}
\hline Index & $\begin{array}{c}\text { Centroid } \\
\text { Mass }\end{array}$ & $\begin{array}{c}\text { Relative } \\
\text { Intensity }\end{array}$ & Area & Index & $\begin{array}{c}\text { Centroid } \\
\text { Mass }\end{array}$ & $\begin{array}{c}\text { Relative } \\
\text { Intensity }\end{array}$ & Area \\
\hline 2 & 144.152369 & 30.59 & 775.88 & 5 & 148.466240 & 8.51 & 56.76 \\
\hline 4 & 148.147897 & 100.00 & 2542.26 & 6 & 149.145287 & 7.06 & 165.60 \\
\hline
\end{tabular}

Table 4. Mononer dominant on mass spectra galic acid as pholyfenol

\begin{tabular}{|c|c|l|l|l|l|l|l|}
\hline Index & $\begin{array}{c}\text { Centroid } \\
\text { Mass }\end{array}$ & $\begin{array}{c}\text { Relative } \\
\text { Intensity }\end{array}$ & Area & Index & $\begin{array}{c}\text { Centroid } \\
\text { Mass }\end{array}$ & $\begin{array}{c}\text { Relative } \\
\text { Intensity }\end{array}$ & Area \\
\hline 10 & 193.128873 & 100.00 & 515.06 & 11 & 194.113103 & 6 & 39.06 \\
\hline
\end{tabular}

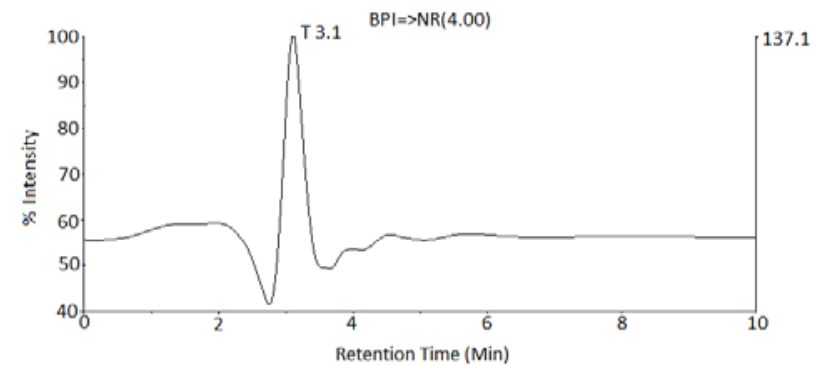

(a)

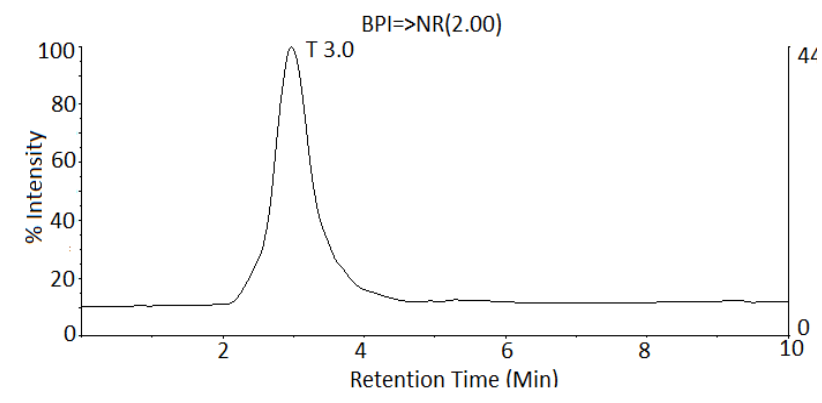

(c)

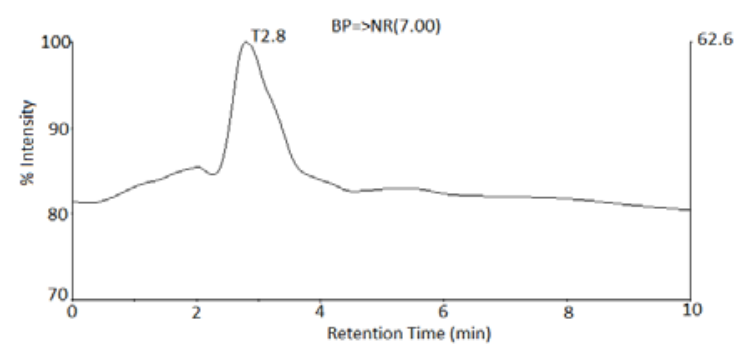

(e)

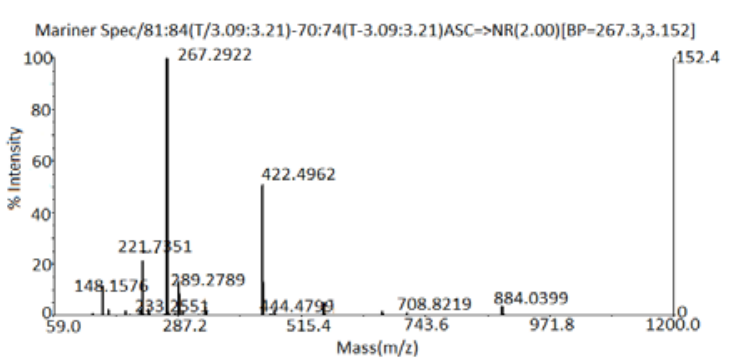

(b)

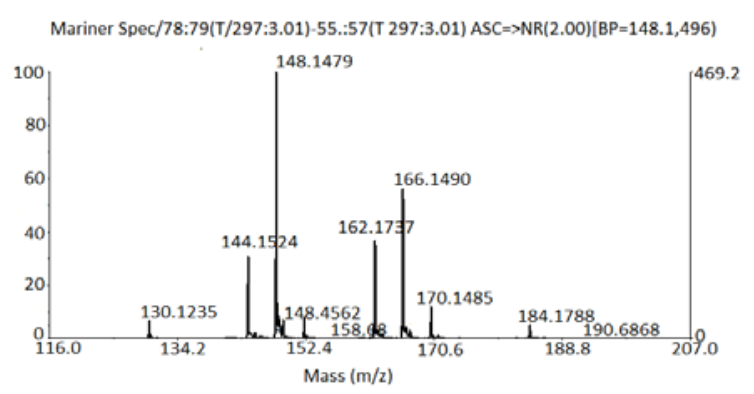

(d)

Mariner Spec/72:76(T/2.74:2.86)-57.:81(T-274:286)ASC $=>(N R=>(2.00)[B P 193.1,88]$

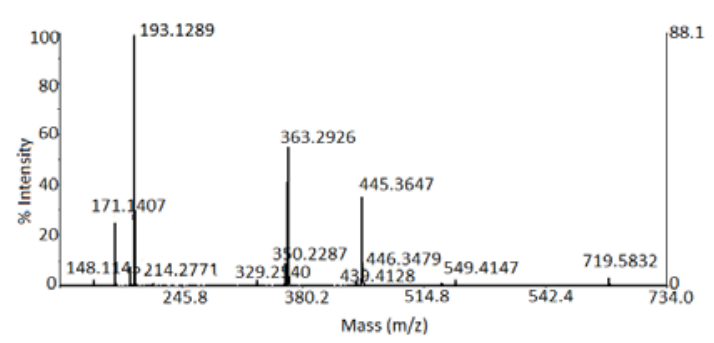

(f)

Figure 4. (a) Chromatogram and (b) mass spectra of peak $T 2.7$ from folic acid standard, (c) chromatogram and (d) mass spectra of peak $\mathrm{T} 2.7$ from glutamic acid standard; (e) chromatogram and (f) mass spectra of peak $\mathrm{T}$ 2.7 from galic acid standard. 
Fermented spinach and fermented broccoli

Identification of fermented spinach monomer in extract (permeate) is yielded 2 peaks T 2.32 and T2.67 with retention time between $0-20$ minutes, as shown in Figure 5a. Mass spectra at peak T2.39 in Figure 5b showed dominant monomer with MWs 203.14, 365.28, 383.32, 527.47 and 707.6 Da., however these MWs do not indicate their specifications both as folic acid and glutamic acid, and galic acid. However, in smaller intensity had been possibility identified monomer as glutamic acid, polyphenol derivates and folic acid derivates with MWs 145.11, 191.14 and 219.12 Da., and relative intensities 5.18, 17.5 and $5.28 \%$, as shown in and Table 5. Mass spectra T2.67 in Figure 5c demonstrated similar trend, in which predominant monomer is not possibility as glutamic acid, folic acid and polyphenol. However, it had been known that its presence of dominant monomer as derivates of folic acid - polyphenol, folic acid and polyphenol with MWs of 219.57, 442.99 and 192.11 Da. with relative intensities 19.78, 0.81 and $1.65 \%$, respectively, as showed in Table 6. In this mass spectra does not find glutamic acid monomer.

Identification on fermented broccoli extract (permeate) monomer was yielded one (1) peak T2.8 with retention time $0-20$ minutes, as shown in Figure 5d Mass spectra at peak T 2.8 in Figure 5e showed dominant monomer with MWs 203.14, 365.27 and 360.34 Da., in which it does not indicate their specifications as both folic acid and glutamic acid, and galic acid. However, it had been reached monomer with MW 226 Da. predicted as folic acid derivates. In smaller intensity, it had beeb identified monomer, which is predicted as glutamic acid and folic acid derivates with MWs 145.11 and 226.26 Da. and relative intensities 0.97 and $100 \%$, as summarized in Table 7. In this mass spectra does not find polyphenol monomer.

Table 5. Mononer dominant on mass spectra extract of fermented spinach ( $\mathrm{T}$ 2.39)

\begin{tabular}{|l|l|l|l|l|l|l|l|}
\hline \multicolumn{1}{|c|}{ Index } & $\begin{array}{c}\text { Centroid } \\
\text { Mass }\end{array}$ & $\begin{array}{c}\text { Relative } \\
\text { Intensity }\end{array}$ & \multicolumn{1}{|c|}{ Area } & Index & $\begin{array}{c}\text { Centroid } \\
\text { Mass }\end{array}$ & $\begin{array}{c}\text { Relative } \\
\text { Intensity }\end{array}$ & Area \\
\hline 2 & 145.117928 & 5.18 & 63.92 & 25 & 219.124876 & 5.28 & 62.13 \\
\hline 11 & 191.137315 & 1.91 & 22.23 & 26 & 223.258844 & 2.58 & 46.09 \\
\hline 12 & 193.148718 & 1.52 & 17.5 & 27 & 225.205521 & 1.67 & 20.2 \\
\hline 33 & 267.223251 & 1.97 & 24.27 & 34 & 269.255779 & 1.33 & 17.62 \\
\hline
\end{tabular}

Table 6. Mononer dominant on mass spectra extract of fermented spinach (T 2.7).

\begin{tabular}{|l|l|l|l|l|l|l|l|}
\hline Index & $\begin{array}{c}\text { Centroid } \\
\text { Mass }\end{array}$ & $\begin{array}{c}\text { Relative } \\
\text { Intensity }\end{array}$ & Area & Index & $\begin{array}{c}\text { Centroid } \\
\text { Mass }\end{array}$ & $\begin{array}{c}\text { Relative } \\
\text { Intensity }\end{array}$ & Area \\
\hline 5 & 192.110091 & 1.65 & 12.06 & 26 & 221.164079 & 12.97 & 12.01 \\
\hline 16 & 219.108183 & 100 & 364.17 & 27 & 221.598863 & 2.62 & 9.43 \\
\hline 17 & 219.418197 & 17.15 & 6.06 & 28 & 222.957096 & 0.45 & 11.68 \\
\hline 18 & 219.477736 & 15.01 & 5.86 & 32 & 264.196889 & 3.51 & 6.59 \\
\hline 19 & 219.568163 & 19.78 & 33.53 & 33 & 265.172767 & 1.63 & 7.51 \\
\hline 20 & 219.851987 & 6.36 & 6.36 & 34 & 267.958877 & 0.74 & 5.66 \\
\hline 21 & 220.070602 & 7.04 & 16.42 & 68 & 399.848955 & 0.44 & 7.65 \\
\hline 22 & 220.271826 & 1.88 & 7.15 & 69 & 442.996832 & 0.81 & 11.1 \\
\hline 23 & 220.795154 & 2.45 & 9.7 & 70 & 444.320225 & 3.89 & 7.09 \\
\hline 24 & 220.998363 & 6.1 & 12.55 & 71 & 445.446764 & 5.96 & 5.75 \\
\hline 25 & 221.064228 & 9.7 & 11.59 & 72 & 445.773859 & 2.95 & 6.18 \\
\hline
\end{tabular}


Table 7. Mononer dominant on mass spectra extract of fermented spinach (T 2.66).

\begin{tabular}{|l|l|l|l|l|l|l|l|}
\hline \multicolumn{1}{|c|}{ Index } & $\begin{array}{c}\text { Centroid } \\
\text { Mass }\end{array}$ & $\begin{array}{c}\text { Relative } \\
\text { Intensity }\end{array}$ & Area & Index & $\begin{array}{c}\text { Centroid } \\
\text { Mass }\end{array}$ & $\begin{array}{c}\text { Relative } \\
\text { Intensity }\end{array}$ & Area \\
\hline 1 & 145.116825 & 0.97 & 23.92 & 12 & 226.688786 & 15.94 & 161.22 \\
\hline 10 & 222.563623 & 0.47 & 60.27 & 13 & 227.271955 & 15.5 & 208.81 \\
\hline 11 & 226.259808 & 100 & 1581.29 & & & & \\
\hline
\end{tabular}

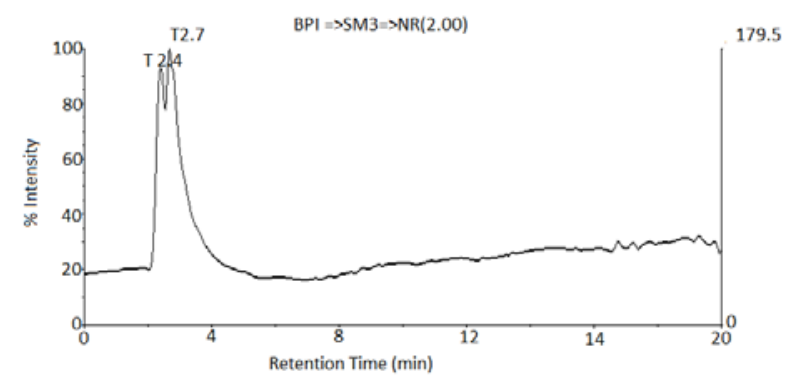

(a)

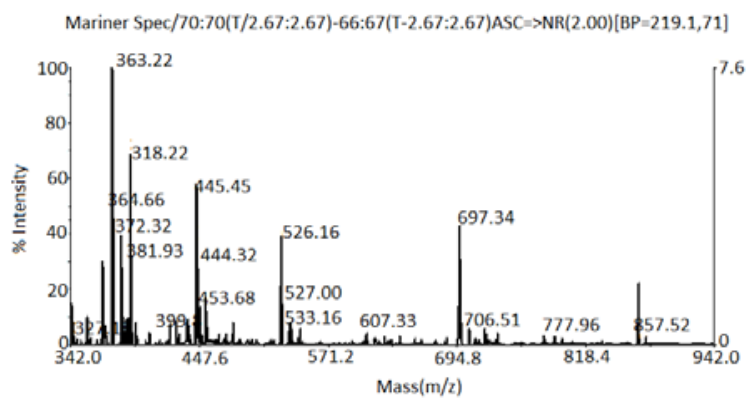

(c)

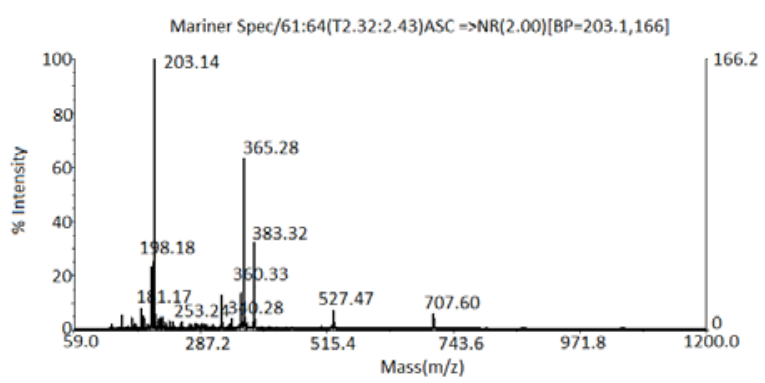

(b)

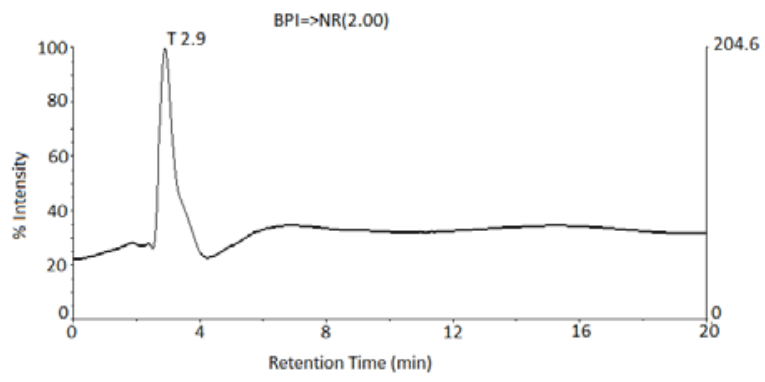

(d)

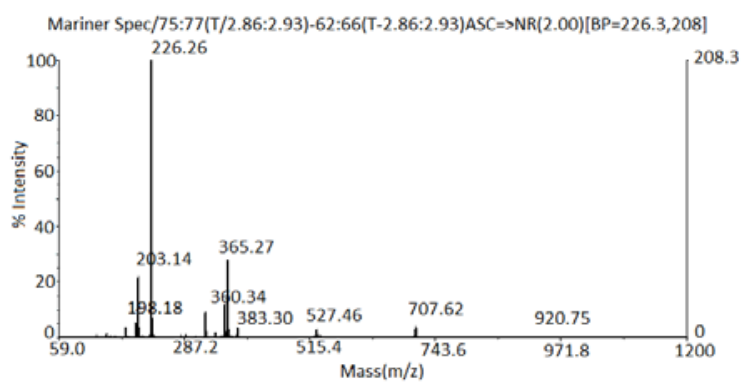

(e)

Figure 5. (a) Chromatogram of fermented spinach monomer, (b) mass spectra of $T 2.67$ and (c) mass spectra of T 2.32 of fermented spinach monomer, (d) chromatogram of fermented broccoli monomer and (e) mass spectra of $\mathrm{T}$ 2.9 of fermented broccoli monomer. 


\section{CONCLUSIONS}

Interaction between type of material (feed) and membrane performance affected on separation of biomass component. More much biomass component retained on retentate (concentrate) compared to passing it in permeate. Dead-end SMFC mode was able to produce both fermented spinach and broccoli concentrates with contents of folic acid of $58.9 \mu \mathrm{g} / \mathrm{mL}$ and $28.1 \mu \mathrm{g} / \mathrm{mL}$, total solids of $6.29 \%$ and $5.76 \%$, total acids of $0.57 \%$ and $0.93 \%$, polyphenol of $0.25 \%$ and $0.06 \%$, and reducing sugar of $105.34 \mu \mathrm{g} / \mathrm{mL}$ and 66.09 $\mathrm{mg} / \mathrm{mL}$. In this condition, recovery of each component in fermented spinach concentrate covering folic acid of 1.07 folds, total solids of 0.95 folds, total acids of 1.01 folds, polyphenol of 3.57 folds, and reducing sugar of 1.22 folds, whereas recovery of each component in fermented broccoli concentrate covering folic acid of 0.65 folds, total solids of 0.97 folds, total acids of 1.04 folds, polyphenol of 0.85 folds, and reducing sugar of 0.68 folds compared to feed. Based on both MW and the best relative intensity, dominant monomer was reached by fermented spinach extract at T 2.7 producing fractination of folic acid, folic acid and polyphenol with MWs 219.57, 442.99 and 192.11 Da. and relative intensities 19.78, 0.81 and $1.65 \%$, respectively. This matter showed that fermented spinach by Kombucha culture had more potential use as source of functional food component for smartness compared to fermented broccoli under both same fermentation and purification process conditions.

\section{REFERENCES}

[1] informasitips, “Asam Folat Penting Untuk Kesehatan, Kumpulan Informasi dan Tips,” Informasitips, 2012. [Online]. Available: http://informasitips.com/asam-folat-penting-untuk-kesehatan. [Accessed: 08-Dec-2014].

[2] T. Hartridge, H. M. Illing, and J. R. Sandy, "The Role of Folic Acid in Oral Clefting,” Br. J. Orthod., vol. 26, no. 2, pp. 115-120, Jun. 1999.

[3] R. Malbaša, E. Lončar, and M. Djuri, "Comparison of the products of Kombucha fermentation on sucrose and molasses,” Food Chem., vol. 106, no. 3, pp. 1039-1045, Feb. 2008.

[4] A. Susilowati, A. Aspiyanto, H. Melanie, and Y. Maryati, "Green tea (Camellia assamica) concentrate as a source of L-theanine used in kombucha fermentation for relaxation drink1) Konsentrat teh hijau (Camellia assamica) sebagai sumber L-theanine yang digunakan pada fermentasi kombucha untuk minuman relaksasi,” $J$. Menara Perkeb., vol. 78, no. 2, pp. 75-83, Mar. 2016.

[5] Kids Health, "Folic Acid and Pregnancy," KidsHealth, $2008 . \quad$ [Online]. Available: https://kidshealth.org/en/parents/preg-folic-acid.html. [Accessed: 08-Dec-2014].

[6] Health Professional Fact Sheet, "Dietary Supplement Fact Sheet: Folate - Health Professional Fact Sheet," Health Professional Fact Sheet, 2012. [Online]. Available: https://ods.od.nih.gov/factsheets/FolateHealthProfessional/. [Accessed: 08-Dec-2014].

[7] H. Naland, Kombucha; teh dengan seribu khasiat. Jakarta: AgroMedia, 2008.

[8] D. D. Cetojevic-Simin, G. M. Bogdanovic, D. D. Cvetkovic, and A. S. Velicanski, "Antiproliferative and antimicrobial activity of traditional Kombucha and Satureja montana L. Kombucha.,” J. BUON., vol. 13, no. 3, pp. 395-401.

[9] G. S. Murugesan, M. Sathishkumar, R. Jayabalan, A. R. Binupriya, K. Swaminathan, and S. E. Yun, "Hepatoprotective and curative properties of Kombucha tea against carbon tetrachloride-induced toxicity.," $J$. Microbiol. Biotechnol., vol. 19, no. 4, pp. 397-402, Apr. 2009.

[10] S. J. O'Keefe, "Nutrition and colonic health: the critical role of the microbiota," Curr. Opin. Gastroenterol., vol. 24, no. 1, pp. 51-58, Jan. 2008.

[11] S. J. D. O'Keefe et al., "Products of the Colonic Microbiota Mediate the Effects of Diet on Colon Cancer Risk," J. Nutr., vol. 139, no. 11, pp. 2044-2048, Nov. 2009.

[12] J. Li and H. A. Chase, "Applications of membrane techniques for purification of natural products," Biotechnol. Lett., vol. 32, no. 5, pp. 601-608, May 2010.

[13] D. . Kwon, S. Vigneswaran, A. . Fane, and R. B. Aim, "Experimental determination of critical flux in crossflow microfiltration,” Sep. Purif. Technol., vol. 19, no. 3, pp. 169-181, Jul. 2000.

[14] I. Ben Hassan, M. Ennouri, C. Lafforgue, P. Schmitz, and A. Ayadi, "Experimental Study of Membrane Fouling during Crossflow Microfiltration of Yeast and Bacteria Suspensions: Towards an Analysis at the Microscopic Level,” Membranes (Basel)., vol. 3, no. 2, pp. 44-68, May 2013.

[15] Y. Zhu, D. Wang, L. Jiang, and J. Jin, "Recent progress in developing advanced membranes for emulsified oil/water separation,” NPG Asia Mater., vol. 6, no. 5, pp. e101-e101, May 2014.

[16] Amicon Bioseparations, Stirred Ultrafiltration Cells User Guide. California, USA: Millipore Corporation, 2008.

[17] P. Cunniff, Official methods of analysis of the AOAC International, 16th ed. Washington (D.C.): AOAC 
International, 1995.

[18] C. G. Pope and M. F. Stevens, “The determination of amino-nitrogen using a copper method.,” Biochem. J., vol. 33, no. 7, pp. 1070-7, Jul. 1939.

[19] Z. Liu, "New techniques for tea catechins extraction,” in International Training Workshop of Tea Science, 2006.

[20] W. Ruengsitagoon and N. Hattanat, "Simple spectrophotometric method for determination of folic acid," in The 4th Annual Northeast Pharmacy Research Conference of “Pharmacy Profession in Harmony,” 2012.

[21] P. Eichhorn and T. P. Knepper, "Electrospray ionization mass spectrometric studies on the amphoteric surfactant cocamidopropylbetaine,” J. Mass Spectrom., vol. 36, no. 6, pp. 677-684, Jun. 2001.

[22] A. Susilowati, Y. M. Iskandar, H. Melanie, Y. Maryati, P. D. Lotulung, and D. G. Aryani, "Pengembangan Konsentrat Sayuran Hijau dan Kacang-kacangan Terfermentasi pada jagung (Zea mays L.) pramasak sebagai sumber asam Folat untuk formula pangan pintar,” Serpong, Tangerang, 2015.

[23] V. de Crécy-Lagard, B. El Yacoubi, R. de la Garza, A. Noiriel, and A. D. Hanson, “Comparative genomics of bacterial and plant folate synthesis and salvage: predictions and validations,” BMC Genomics, vol. 8, no. 1, p. 245, Jul. 2007.

[24] P. M. Hauser and I. G. Macreadie, "Isolation of the Pneumocystis carinii dihydrofolate synthase gene and functional complementation in Saccharomyces cerevisiae,” FEMS Microbiol. Lett., vol. 256, no. 2, pp. 244-250, Mar. 2006.

[25] J. Du and S. W. Hoag, "Characterization of Excipient and Tableting Factors That Influence Folic Acid Dissolution, Friability, and Breaking Strength of Oil- and Water-Soluble Multivitamin with Minerals Tablets,” Drug Dev. Ind. Pharm., vol. 29, no. 10, pp. 1137-1147, Jan. 2003.

[26] PCI Membrane System Inc, “Membrane Technology For Process Industry.” Milford, U.S.A, 2005.

[27] Roilbilad, “Teknologi membran untuk aplikasi BRM,” Roilbilad, 2010. [Online]. Available: https://roilbilad.wordpress.com/2010/07/22/2-teknologi-membran-untuk-aplikasi-brm/. [Accessed: 25-Oct2016].

[28] R. Jayabalan, P. Subathradevi, S. Marimuthu, M. Sathishkumar, and K. Swaminathan, "Changes in free-radical scavenging ability of kombucha tea during fermentation,” Food Chem., vol. 109, no. 1, pp. 227-234, Jul. 2008.

[29] H.-D. Belitz and W. Grosch, Food chemistry, 2. ed. Berlin : Springer, 1999. 